\title{
Research Square \\ Characteristics and trend of extreme temperature in Spatio-temporal context, South Xinjiang China.
}

\section{Research Article}

Keywords:

Posted Date: April 1st, 2022

DOI: https://doi.org/10.21203/rs.3.rs-346394/v2

License: (c) (1) This work is licensed under a Creative Commons Attribution 4.0 International License. Read Full License 


\section{Abstract}

The full text of this preprint has been withdrawn, as it was submitted in error. Therefore, the authors do not wish this work to be cited as a reference. Questions should be directed to the corresponding author.

\section{Full Text}

The authors have withdrawn this preprint from Research Square. 